\title{
PENGARUH CONTEXTUAL TEACHING AND LEARNING DAN SELF REGULATED LEARNING TERHADAP KEMAMPUAN KONEKSI MATEMATIS
}

\author{
${ }^{1}$ Syahrul Anwar, ${ }^{2}$ Heni Pujiastuti, ${ }^{3}$ Anwar Mutaqin \\ ${ }^{1,2,3}$ Universitas Sultan Ageng Tirtayasa, Jl. Raya Jakarta, Kota Serang, Banten (0254)280330, Indonesia \\ e-mail: anwarsyahrul291@gmail.com
}

\begin{abstract}
Abstrak
Penelitian ini bertujuan untuk mengetahui pengaruh model contextual teaching and learning dan self-regulated learning terhadap kemampuan koneksi matematis siswa, ditinjau dari siswa kategori self-regulated learning (tinggi, sedang, rendah). Populasi penelitian ini adalah seluruh siswa SMK Darul Fikri Pandeglang, sampel dipilih dua kelas secara acak, yaitu kelas X RPL 1 sebagai kelas eksperimen, dan kelas X TSM 1 sebagai kelas kontrol. Pengumpulan data dilakukan melaui tes dan non tes. Tes berupa 6 soal kemampuan koneksi matematis, sedangkan non tes berupa soal angket self-regulated learning. Pretest diberikan sebagai tes awal sebelum perlakuan contextual teaching and learning, sedangkan posttes dilakukan setelah diberikan perlakuan contextual teaching and learning. Hasil yang diperoleh setelah proses pembelajaran dengan contextual teaching and learning dan self regulated learning terlihat adanya pengaruh yang signifikan terhadap kemampuan koneksi matematis siswa. Dengan demikian, dapat disimpulkan bahwa pembelajaran dengan model contextual teaching and learning dan self-regulated learning berpengaruh terhadap kemampuan koneksi matematis siswa.
\end{abstract}

Kata Kunci : Contextual Teaching and Learning (CTL), Self Regulated Learning (SRL), Kemampuan Koneksi Matematis

\begin{abstract}
This study aims to determine the effect of contextual teaching and learning models and self-regulated learning on students 'mathematical connection skills, in terms of students' self-regulated learning categories (high, medium, low). The population of this study was all students of the Darul Fikri Pandeglang Vocational School, the sample was chosen by two classes randomly, namely class X RPL 1 as the experimental class, and class X TSM 1 as the control class. Data collection is done through tests and non-tests. The test is in the form of 6 questions about mathematical connection skills, while the non-test questions are in the form of a self-regulated learning questionnaire. Pretest was given as a preliminary test before the treatment of contextual teaching and learning, while posttes were carried out after being given the treatment of contextual teaching and learning. The results obtained after the learning process with contextual teaching and learning and self regulated learning showed a significant influence on students' mathematical connection skills. Thus, it can be concluded that learning with the contextual teaching and learning model and self-regulated learning influences students' mathematical connection skills.
\end{abstract}

Keywords: Contextual Teaching and Learning (CTL), Self Regulated Learning (SRL), Mathematical Connection Ability

\section{PENDAHULUAN}

Data yang menunjukan kemampuan koneksi matematis masih rendah, hasil penelitian Sugiman (2008 : 10), menyatakan bahwa rata-rata persentase penguasan untuk setiap aspek koneksi adalah inter topik matematika $63 \%$, antar topik matematika $40 \%$, matematika dengan pelajaran lain 56\%, dan matematika dengan kehidupan nyata 55\%. Penelitian Sugiman, tentang kemampuan koneksi matematis masih rendah. 
Berdasarkan pemaparan tentang kemampuan koneksi matematis tersebut, menujukkan bahwa, kemampuan koneksi matematis merupakan kemampuan yang penting untuk dikembangkan pada siswa sekolah menengah. Kurangnya kemampuan siswa dalam koneksi matematis adalah salah satu penyebab timbulnya kesulitan dalam menyelesaikan sebuah persoalan yang berakibat rendahnya kemampuan matematika. Kemampuan koneksi matematis adalah tingkat kemampuan siswa untuk mengaitkan materi matematika dengan materi matematika. Hubungan matematika dengan ilmu pengetahuan, hubungan matematika dengan kehidupan nyata. Menurut Gordah (2009), bahwa kelemahan yang paling banyak ditemui pada hasil jawaban siswa dalam kemampuan koneksi matematis adalah siswa tidak dapat menjawab hubungan atau konsep matematika yang digunakan.

Kenyataan di lapangan, menunjukkan bahwa kemampuan koneksi masih rendah. Dari pengamatan dan pembicaraan peneliti dengan guru matematika SMK Darul Fikri Pandeglang, terekam kenyataan bahwa sedikit sekali siswa yang belajar matematika disertai kemampuan koneksi matematika yang baik. Hal inipun terlihat saat siswa diberikan soal atau masalah yang sedikit berbeda dari contoh soal yang diberikan gurunya, kinerja mereka menunjukkan seolah-olah belum pernah belajar materi atau contoh soal yang mirip dengan soal tersebut, banyak faktor yang menjadi penyebab rendahnya kemampuan koneksi matematis diantaranya: Malas mempelajari kembali hasil pembelajaran sebelumnya yang telah dibahas dan siswa enggan bertanya selama dalam proses pembelajaran walaupun sebenarnya mereka belum mengerti.

Dari kemampuan koneksi matematis yang masih rendah dan menyadari akan pentingnya hal tersebut. Guru diharapkan dalam mengupayakan pembelajaran dengan menerapkan model dan pendekatan pembelajaran yang dapat memberikan peluang dan mendorong siswa untuk melatih kemampuan koneksi matematis. Salah satu cara memperbaiki rendahnya kemampuan koneksi matematis siswa adalah dengan menggunakan pendekatan pembelajaran yang lebih mendukung aktivitas siswa dalam memahami suatu materi dan lebih menekankan siswa berperan aktif dalam pembelajaran. Model pembelajaran yang tepat efektif dan harus diterapkan sebagai solusi untuk meningkatkan kemampuan koneksi matematis siswa adalah model pembelajaran Contextual Teaching and Learning (CTL).

Selain dengan model pembelajaran CTL, aspek penting lainnya yang harus diperhatikan yang efektif dan diperkirakan dapat meningkatkan kemampuan koneksi matematis siswa, dalam proses pembelajaran matematika adalah self-regulated learning (kemandirian belajar).

Pengaruh Contextual Teaching and Learning dan Self Regulated Learning terhadap Kemampuan 
Menurut Sugandi (2013), self-regulated learning adalah suatu sikap siswa yang memiliki karakteristik berinisiatif belajar, mendiagnosis kebutuhan belajar, menetapkan tujuan belajar, memonitor, mengatur dan mengontrol kinerja atau belajar, memandang kesulitan sebagai tantangan, mencari dan memanfaatkan sumber belajar yang relevan, memilih dan menerapkan strategi belajar, mengevaluasi proses dan hasil belajar, serta self-concept (konsep diri). Dengan memiliki kemandirian belajar siswa akan mempunyai tujuan yang jelas, dapat menilai diri sendiri, mempertimbangkan kemajuan belajar, seperti pandangan dan kepercayaan yang tinggi tentang kemampuan dirinya, menilai pembelajaran, faktor yang berpengaruh dalam belajar, dan antisipasi dampak (self-efficacy) selama proses pembelajaran.

Kemampuan koneksi matematis merupakan salah satu kemampuan berpikir tingkat tinggi yang sangat penting dan harus dikembangkan karena dalam pembelajaran matematika setiap konsep berkaitan satu sama lain dengan konsep lainnya. Rendahnya kemampuan koneksi matematis berdampak pada rendahnya prestasi dan hasil belajar matematis siswa. Menyadari akan pentingnya kemampuan koneksi matematis siswa dalam pembelajaran matematika tersebut. Dibutuhkanlah model pendekatan pembelajaran yang tepat, efektif dan diperkirakan dapat meningkatkan kemampuan koneksi matematis siswa sebagai perlakuan, yaitu dengan model pendekatan pembelajaran contextual teaching and learning (CTL). Selain model pendekatan pembelajaran matematika tersebut yang tepat dan dikaitkan dalam kehidupan sehari-hari sebagai perlakuan. Juga diberikan perlakuan yang lain yaitu pembelajaran berbasis kemandirian belajar siswa (SRL). Kemandirian dalam belajar bagi siswa merupakan suatu langkah yang efektif dan efisien dalam memaksimalkan kemampuan siswa tanpa harus bergantung pada guru, proses belajar mengajar akan lebih optimal sehingga diperkirakan dapat meningkatkan kemampuan koneksi matematis siswa.

Untuk mencapai tujuan pembelajaran perlulah dicari alternatif pembelajaran yang dapat memberikan kesempatan kepada siswa untuk mengungkapkan ide/gagasan matematika secara optimal serta menumbuhkan penalaran sehingga siswa lebih berfikir dan mengkoneksikan dalam belajar matematika. Salah satu model pembelajaran yang diterapkan dalam proses pembelajaran matematika adalah model contextual teaching and learning (CTL) dan ditinjau dari self regulated learning (tinggi, sedang, rendah) terhadap kemampuan koneksi matematis siswa. Pendekatan contextual teaching and learning pembelajaran merupakan salah satu alternatif pilihan guru dalam proses pembelajaran untuk mencapai tujuan yang telah ditetapkan.

Prima, Vol. 3, No. 2, Juli 2019, 116-133. 


\section{METODE PENELITIAN}

\section{Contextual Teaching and Learning (CTL)}

Pembelajaran kontekstual (CTL) adalah pembelajaran yang membantu guru mengaitkan antara materi yang diajarkan dengan situasi dunia nyata siswa dan mendorong siswa membuat hubungan antara pengetahuan yang dimiliki dengan penerapannya dalam kehidupan seharihari.

Langkah-langkah pembelajaran CTL antara lain :

1. Mengembangkan pemikiran bahwa anak akan belajar lebih bermakna dengan cara bekerja sendiri, menemukan sendiri, dan mengkonstruksi sendiri pengetahuan dan ketrampilan barunya.

2. Melaksanakan sejauh mungkin kegiatan inquiri untuk semua topik

3. Mengembangkan sifat ingin tahu siswa dengan bertanya

4. Menciptakan masyarakat belajar

5. Menghadirkan model sebagia contoh belajar

6. Melakukan refleksi diakhir pertemuan.

7. Melakukan penialain yang sebenarnya dengan berbagai cara.

Ciri kelas yang menggunakan pendekatan kontekstual
a. Pengalaman nyata
b. Kerja sama, saling menunjang
c. Gembira, belajar dengan bergairah
d. Pembelajaran terintegrasi
e. Menggunakan berbagai sumber
f. Siswa aktif dan kritis
g. Menyenangkan, tidak membosankan
h. Sharing dengan teman
i. Guru kreatif

Kelebihan dan Kekurangan pembelajaran kontekstual

Menurut Manoy J.T (2004), kelebihan dan kekurangan tersebut adalah:

1. Kelebihan

a. Pemahaman siswa terhadap konsep matematika tinggi, sebab konsep ditemukan sendiri oleh siswa, karena siswa menerapkan apa yang dipelajari dengan kehidupan sehari-hari.

b. Siswa terlibat aktif dalam memecahkan masalah dan memiliki keterampilan berfikir yang lebih tinggi, karena siswa di latih untuk menggunakan berfikir kritis dan kreatif

\section{Pengaruh Contextual Teaching and Learning dan Self Regulated Learning terhadap Kemampuan


dalam menggunakan data, memahami masalah atau memecahkan suatu masalah.

c. Pengetahuan tentang materi pembelajaran tertanam berdasarkan skema yang dimiliki siswa, sehingga pembelajaran CTL akan lebih bermakna.

d. Siswa dapat merasakan manfaat pembelajaran matematika, sebab masalah yang ditampilkan berkaitan dengan masalah yang konteks bagi siswa. Hal ini dapat mengakibatkan tingkat motivasi dan kesukaran siswa terhadap belajar matematika semakin tinggi.

e. Siswa menjadi lebih mandiri.

f. Pencapaian ketuntasan belajar siswadapat diharapkan.

2. Kelemahan

a. Waktu yang dibutuhkan dalam pembelajaran amat banyak karena siswa dituntut menemukan sendiri suatu konsep sedangkan guru hanya berperan sebagai fasilitator, hal ini dapat berakibat pada tahap awal materi kadang-kadang tidak tuntas.

b. Tidak semua komponen pembelajaran CTL dapat diterapkan pada seluruh materi pelajaran tetapi hanya dapat diterapkan pada materi pembelajaran yang mengandung prasyarat yang dapat diterapkan CTL.

c. Sulit untuk mengubah paradigma guru, yaitu guru sebagai pengajar ke guru sebagai fasilitator dan mitra siswa dalam belajar.

Dalam suatu pembelajaran tentu ada kelemahan-kelemahannya. Agar suatu pembelajaran dapat berjalan dengan baik maka tugas kita sebagai guru adalah meminimalkan kelemahan-kelemahan tersebut dengan bekerja lebih keras.

\section{Self-Regulated Learning (SRL)}

Self-regulated learning adalah suatu upaya siswa aktif untuk mengembangkan pengetahuan yang didapat dengan menggunakan cara-cara yang relevan dan tidak terbatas hanya pada materi pelajaran yang didapat siswa dari lingkungan sekolah.

Menurut Fitria, (2009), self-regulated learning dilandasi oleh paham konstruktivisme dimana pembelajaran dirancang dan dikelola sedemikian rupa sehingga mampu mendorong siswa untuk mengorganisasi pengalamannya sendiri menjadi suatu pengetahuan baru yang bermakna. Elyaniar, (2012), mengemukakan empat prinsip self-regulated learning yaitu 1) mempersiapkan lingkungan belajar, 2) mengorganisasi materi, 3) memonitor kemajuan sendiri, dan 4) melakukan evaluasi terhadap kinerja.

Menurut Lestari dan Widada (2017),sintesis langkah pembelajaran SRL berbasis pemecahan masalah.

Prima, Vol. 3, No. 2, Juli 2019, 116-133. 
1) Analisis topik

2) Mengamati atau menyimak permasalahan yang ada

3) Merencanakan, melakukan diskusi kelompok untuk menentukan rencana kegiatan pemecahan masalah terkait pertanyaan yang didapat dan mendiskusikan rencana sumber belajar yang relevan untuk mendukung pembelajaran.

4) Mengumpulkan informasi

5) Mengasosiasikan (mengolah informasi)

6) Pemecahan masalah, melakukan diskusi kelompok atau antar kelompok untuk menjawab hal-hal yang belum dimengerti dan guru memberikan arahan dan bimbingan

7) Mengkomunikasikan yaitu menyampaikan hasil pemecahan masalah

8) Mengevaluasi

9) Modifikasi yaitu menyimpulkan pembelajaran, melakukan perbaikan strategi yang digunakan jika mengalami kesulitan

\section{Kemampuan Koneksi Matematis}

Kemampuan koneksi matematis adalah kemampuan mengaitkan konsep-konsep matematika baik antar konsep dalam matematika itu sendiri maupun mengaitkan konsep matematika dengan konsep dalam bidang lainnya Ruspiani, (2000). Aspek koneksi antar topik matematika akan membantu siswa menghubungkan konsep-konsep matematik untuk menyelesaikan suatu situasi permasalahan matematika, yang artinya bahwa pelajaran matematika yang tersebar ke dalam topik-topik aljabar, pengukuran, geometri, peluang, statistika dan trigonometri, dalam pembelajarannya dapat dikaitkan satu sama lainnya.

Tujuan siswa memiliki kemampuan koneksi matematika menurut NCTM (2000), agar siswa mampu untuk: (1) mengenali representasi yang ekuivalen dari suatu konsep yang sama; (2) mengenali hubungan prosedur satu represntasi ke prosedur representasi yang ekuivalen; (3) menggunakan dan menilai koneksi beberapa topik matematika; dan (4) menggunakan dan menilai koneksi antara matematika dan disipin ilmu lain.

Sedangkan menurut Anandita (2015), indikator yang digunakan untuk menganalisis kemampuan koneksi matematis siswa adalah sebagai berikut: (1) menemukan hubungan dari berbagai representasi tentang konsep dan prosedur matematika. (2) memahami hubungan antar topik dalam matematika. (3) mampu menggunakan matematika dalam penyelesaian masalah dalam kehidupan sehari-hari. (4) memahami representasi konsep yang ekuivalen. (5)

Pengaruh Contextual Teaching and Learning dan Self Regulated Learning terhadap Kemampuan 
menemukan hubungan antara prosedur satu dengan lainnya yang ekuivalen. (6) menggunakan koneksi antara matematika dengan matematika sendiri maupun dengan ilmu yang lain.

Penelitian dilakukan dengan menggunakan metode eksperimen. Penelitian eksperimen merupakan penelitian yang sistematis, logis dan teliti di dalam melakukan kontrol terhadap kondisi. Dalam penelitian eksperimen dimanipulasikan sesuatu secara secara stimuli, tritmen atau kondisi-kondisi eksperimental, kemudian mengobservasi pengaruh yang diakibatkan oleh adanya perlakuan atau manipulasi tersebut (Yatim Riyanto, 2010:35). Subjek penelitian ini adalah siswa kelas X RPL 1 dan kelas X TSM 1 SMK Darul Fikri Pandeglang. Penelitian ini dibagi menjadi 3 tahapan yaitu tahap persiapan, tahap pelaksanaan dan tahap analisis. Teknik pengumpulan data dalam penelitian ini menggunakan tes. Untuk itu diberikan kelas eksperimen dan kelas kontrol. Setelah diberikan perlakuan, perubahannya diukur untuk mengetahui ada tidaknya perubahan dan mengetahui bagaimana variabel yang diteliti. Desain eksperimen yang dipilih adalah treatment by level $2 \times 3$. Pada penelitian ini terdapat tiga variabel yang terdiri dari satu variabel terikat yaitu kemampuan koneksi matematis siswa dan satu varibel bebas yaitu model pembelajaran contextual teaching and learning (CTL) serta yaitu self-regulated learning sebagai variabel kontrol untuk meninjau kelompok kategori SRL (tinggi, sedang, dan rendah). Teknik analisis data dalam penelitian ini dengan menggunakan uji hipotesis untuk melihat pengaruh pendekatan contextual teaching and learning (CTL) dan self-regulated learning terhadap kemampuan konksi matematis siswa.

\section{HASIL DAN PEMBAHASAN}

\section{Hasil}

Penelitian yang telah dilakukan bertujuan untuk menganalisis pengaruh model pembelajaran contextual teaching and learning (CTL) dan self-regulated learning (SRL) terhadap kemampuan koneksi matematis siswa ditinjau dari SRL (tinggi, sedang, rendah).

Data kemampuan koneksi matematis diukur berdasarkan faktor SRL (tinggi, sedang, rendah) yang diperlakukan baik pada kelas eksperimen yang diberikan model CTL dan juga kelas pada kontrol yang diberikan pembelajaran ekspositori. Self-regulated learning ini terkait dengan materi atau pengalaman selama proses pembelajaran yang pernah diperoleh siswa. Diukur dengan kategori soal pernyataan berupa pilihan yaitu: 1) sangat setuju (SS), 2) setuju (S), 3) Netral (N), 4) sangat tidak setuju (STS) dan 5) tidak setuju (TS) yang diberikan ke pada siswa dengan disediakan tanda ceklist yang tersedia di form pernyataan. Setelah jawaban siswa terkumpul kemudian direkap, dan diolah berdasarkan penggolongan

Prima, Vol. 3, No. 2, Juli 2019, 116-133. 
kategori SRL tinggi (T), sedang (S), dan rendah (R) berdasarkan skor yang diperoleh masingmasing siswa.

Untuk mengkategorisasikan SRL tersebut digunakan rata-rata dan simpangan baku dari keseluruhan data dari kedua kelompok peserta didik. SRL keseluruhan antara rata-rata kelas eksperimen adalah 79 dan kelas kontrol adalah 77. Sedangkan untuk simpangan baku kelas eksperimen adalah 20 dan kelas kontrol adalah 19. Kemudian dilakukan batas-batas kategori SRL (tinggi, sedang, rendah) yang diperoleh berdasarkan rata-rata \& simpangan baku yang hasilnya disajikan pada Tabel 1 sebagai berikut:

Tabel 1. Kategorisasi SRL

\begin{tabular}{ccc}
\hline \multirow{2}{*}{ Taraf } & \multicolumn{2}{c}{ Skor SRL Kelas } \\
& Eksperimen & Kontrol \\
\hline Tinggi & Skor $\geq 99$ & Skor $\geq 96$ \\
Sedang & $60<$ Skor $<98$ & $58<$ Skor $<95$ \\
Rendah & Skor $\leq 59$ & Skor $\leq 57$ \\
\hline
\end{tabular}

Sumber: (Lestari \& Yudhanegara: 2017)

Kategorisasi sebagaimana pada Tabel 1 di atas digunakan untuk mengkategorisasi SRL pada kedua kelompok siswa yaitu kelompok pembelajaran dengan contextual teaching and learning (CTL) dan kelompok pembelajaran ekspositori (PE). Berikut adalah sebaran data jumlah sampel pada masing-masing kategori self-regulated learning (SRL) untuk kedua kelompok pembelajaran.

Tabel 2. Jumlah Sampel Berdasarkan SRL

\begin{tabular}{lccc}
\hline \multicolumn{1}{c}{ Kategori SRL } & \multicolumn{2}{c}{ Model Pembelajaran } & Jumlah Siswa \\
\hline Tinggi & CTL & Ekspositori & \\
Sedang & 7 & 7 & 14 \\
Rendah & 12 & 12 & 24 \\
\multicolumn{1}{c}{ Total Siswa } & 7 & 7 & 14 \\
\hline
\end{tabular}

Jumlah siswa dalam sampel berdasarkan kategori SRL baik pada kelompok pembelajaran dengan contextual teaching and learning (CTL) maupun dengan pembelajaran ekspositori (PE) sama-sama cenderung normal. Jumlah siswa pada kelompok kategori Tinggi dan Rendah lebih sedikit dan jumlah siswa pada kategori sedang lebih banyak. Pola sebaran jumlah siswa berdasarkan kategori SRL antara kedua kelompok CTL dan PE cenderung sama.

Pengaruh Contextual Teaching and Learning dan Self Regulated Learning terhadap Kemampuan 
Hasil data tes siswa sebelum dan sesudah dilaksanakannya pembelajaran dengan model contextual teaching and learning dan self regulated learning (tinggi, sedang, rendah) di kelas X RPL. 1 dan kelas X TSM.1 dapat dilihat pada tabel 3 berikut.

Tabel 3. Rekapitulasi Analisis Statistik Deskriptif Kemampuan Koneksi matematis

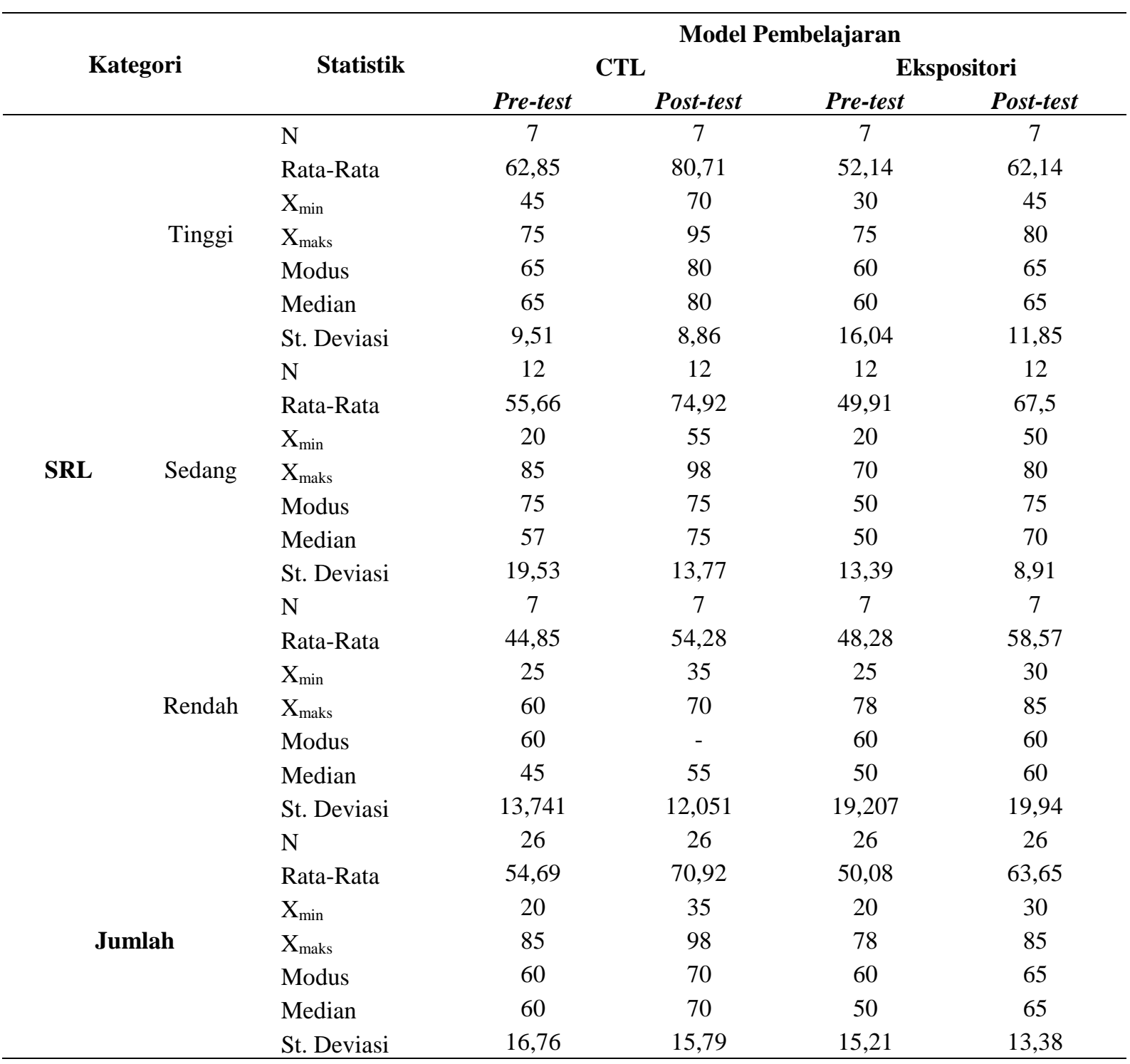

Pada Tabel 3 tersebut terlihat data nilai pre-tes kemampuan koneksi matematis menunjukkan, nilai rata-rata pre-test pada kelas eksperimen dengan pembelajaran CTL adalah 54,69 lebih tinggi dari pada pembelajaran ekspositori adalah 50,08. Nilai modus pretest pada kelas eksperimen dengan pembelajaran CTL adalah 60, nilainya sama dengan nilai pembelajaran ekspositori adalah 60. Nilai median pre-test pada kelas eksperimen dengan pembelajaran CTL adalah 60, lebih tinggi dari pada pembelajaran ekspositori adalah 50. Nilai simpangan baku pre-test pada kelas eksperimen dengan pembelajaran CTL adalah 16,76, lebih tinggi dari pada pembelajaran ekspositori adalah 15,21. Sedangkan dari data nilai post-

Prima, Vol. 3, No. 2, Juli 2019, 116-133. 
test kemampuan koneksi matematis menunjukkan, nilai rata-rata post-test pada kelas eksperimen dengan pembelajaran CTL adalah 70,92 lebih tinggi dari pada pembelajaran ekspositori adalah 63,65. Nilai modus post-test pada kelas eksperimen dengan pembelajaran CTL adalah 70, lebih tinggi dari pada pembelajaran ekspositori adalah 65. Nilai median posttest pada kelas eksperimen dengan pembelajaran CTL adalah 70, lebih tinggi dari pada pembelajaran ekspositori adalah 65. Nilai simpangan baku post-test pada kelas eksperimen dengan pembelajaran CTL adalah 15,79 lebih rendah dari pada pembelajaran ekspositori adalah 13,38 .

Berdasarkan hasil analisis data yang telah dilakukan, maka dapat dikemukakan beberapa hal berikut ini:

\section{Peningkatan kemampuan koneksi matematis siswa yang belajar dengan} pembelajaran contextual teaching and learning (CTL) lebih baik dibandingkan dengan pembelajaran ekspositori.

Hipotesis statistika untuk menguji hipotesis penelitian. Hasil penghitungan diperoleh nilai-p sebesar 0,08. Nilai tersebut lebih dari 0,05 , sehingga $\mathrm{H}_{0}$ diterima. Ini berarti data bervariansi sama atau homogen.

Perhitungan data postest kemampuan koneksi matematis dengan ANAVA dua jalur dapat dilihat pada Tabel 4 berikut:

Tabel 4. Hasil Uji ANAVA Dua Jalur Pengaruh Model Pembelajaran Contextual Teaching and Learning dan Self-regulated Learning serta Interaksinya Terhadap Kemampuan Koneksi matematis Tests of Between-Subjects Effects

\begin{tabular}{lr|r|r|r|r}
\hline & $\begin{array}{c}\text { Type III Sum } \\
\text { of Squares }\end{array}$ & Df & $\begin{array}{c}\text { Mean } \\
\text { Squar }\end{array}$ & & \\
Source & .186 & 1 & .186 & 7.700 & .008 \\
\hline Pembelajaran & .355 & 2 & .178 & 7.351 & .002 \\
SRL & .200 & 2 & .100 & 4.127 & .022 \\
\hline Pembelajaran * SRL & &
\end{tabular}

Berdasarkan data dalam Tabel 4 hasil perhitungan ANAVA dengan berbantu SPSS-23 pada kedua kelompok data di atas menunjukkan bahwa pada pembelajaran Sig. $=0.008<0.05$ pada taraf signifikan 0.05 maka $\mathrm{H}_{0}$ ditolak. Hal ini berarti bahwa terdapat perbedaan yang signifikan pada kemampuan koneksi matematis siswa yang mendapat perlakuan model pembelajaran CTL dengan siswa yang mendapat perlakuan dengan model pembelajaran ekspositori. Selanjutnya data di uji-t dengan menggunakan SPSS, mendapatkan hasil seperti tabel 5 berikut:

\footnotetext{
Pengaruh Contextual Teaching and Learning dan Self Regulated Learning terhadap Kemampuan Koneksi Matematis 
Tabel 5 Uji Perbedaan Rataan Skor Koneksi matematis Antara Pembelajaran

\begin{tabular}{ccccc}
\hline \multicolumn{2}{c}{ t-test for Equality of Means } & \multirow{2}{*}{ Keterangan } & \multirow{2}{*}{ Kesimpulan } \\
T & Df & Sig. (2-tailed) & & \\
\hline 2.462 & 50 & .017 & Ho Ditolak & Terdapat Perbedaan \\
\hline
\end{tabular}

Dari tabel 4 dapat terlihat nilai sig $0.017<0.05$, maka dapat disimpulkan perbedaan kemampuan koneksi matematis siswa yang mendapat perlakuan model pembelajaran CTL lebih tinggi dari pada yang mendapat perlakuan pembelajaran ekspositori.

\section{Terdapat Pengaruh Self-Regulated Learning terhadap Kemampuan Koneksi Matematis Siswa}

Berdasarkan data dalam Tabel 4 hasil perhitungan ANAVA dengan berbantu SPSS-23 pada kedua kelompok data di atas menunjukkan bahwa pada SRL Sig. $=0.002<0.05$ pada taraf signifikan 0.05 maka $\mathrm{H}_{0}$ ditolak. Hal ini berarti bahwa terdapat pengaruh SRL terhadap kemampuan koneksi matematis siswa.

\section{Interaksi antara Model Pembelajaran dengan Self Regulated Learning Terhadap} Kemampuan Koneksi matematis

Berdasarkan data dalam Tabel 4 terlihat bahwa Pembelajaran SRL memiliki nilai Sig. = $0.022<0.05$ pada taraf signifikan $5 \%$ maka $\mathrm{H}_{0}$ ditolak. Hal ini berarti bahwa terdapat interaksi.

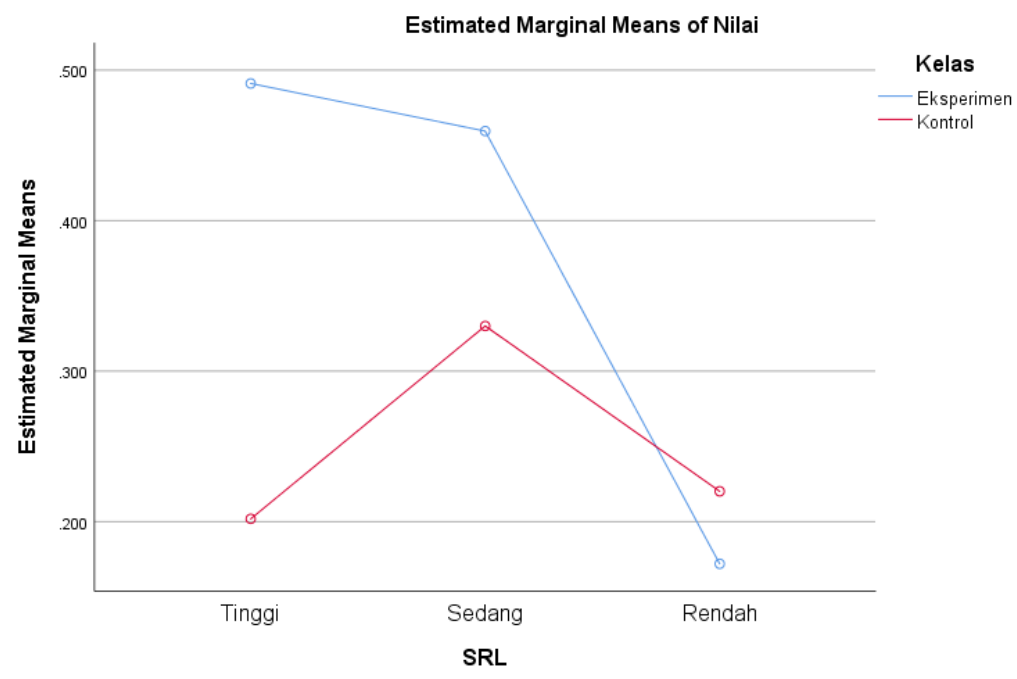

Gambar 1. Interaksi Antara Model Pembelajaran dan self-regulated learning terhadap Kemampuan Koneksi matematis

4. Perbedaan Peningkatan kemampuan koneksi matematis antara SRL Tinggi yang diajar model Pembelajaran CTL dengan SRL tinggi yang diajar model ekspositori. 
Karena terdapat interaksi, data kemudian dilanjutkan uji-t untuk menguji kesimpulan dari hipotesis. Adapun hasil dari uji-t disajikan pada table berikut ini:

Tabel 6. Uji Perbedaan Rataan Skor Antara Kelompok Berdasarkan Self-Regulated Learning

\begin{tabular}{|c|c|c|c|c|c|}
\hline \multirow[b]{2}{*}{ SRL } & \multicolumn{3}{|c|}{$\begin{array}{c}\text { t-test for Equality of } \\
\text { Means }\end{array}$} & \multirow[b]{2}{*}{ Keterangan } & \multirow[b]{2}{*}{ Kesimpulan } \\
\hline & $\mathbf{T}$ & Df & $\begin{array}{l}\text { Sig. (2- } \\
\text { tailed) }\end{array}$ & & \\
\hline Tinggi & 3.966 & 12 & .002 & Ho Ditolak & $\begin{array}{l}\text { Terdapat } \\
\text { Perbedaan }\end{array}$ \\
\hline Sedang & 1.716 & 22 & .100 & $\mathrm{H}_{0}$ Diterima & $\begin{array}{c}\text { Tidak Terdapat } \\
\text { Perbedaan }\end{array}$ \\
\hline Rendah & -.844 & 12 & .415 & $\mathrm{H}_{0}$ Diterima & $\begin{array}{c}\text { Tidak Terdapat } \\
\text { Perbedaan }\end{array}$ \\
\hline
\end{tabular}

Dari tabel 6 di atas, maka dapat terlihat bahwa hanya SRL tinggi yang memiliki perbedaan sedangkan SRL sedang dan SRL rendah tidak terdapat perbedaan. Maka dapat disimpulkan bahwa siswa yang memiliki SRL Tinggi dengan menggunakan model pembelajaran CTL memiliki kemampuan koneksi matematis yang lebih tinggi dibandingkan dengan Siswa SRL Tinggi menggunakan model pembelajaran ekspositori.

\section{Pembahasan Penelitian}

Tujuan dari penelitian ini adalah untuk mengetahui pengaruh penerapan model pembelajaran CTL dan self-regulated learning terhadap koneksi matematis siswa. Adapun pembahasannya sebagai berikut:

\section{Perbedaan peningkatan kemampuan koneksi matematis siswa yang belajar} menggunakan model pembelajaran CTL lebih baik dibandingkan dengan siswa yang belajar menggunakan model pembelajaran ekspositori.

Berdasarkan pengujian hipotesis pertama menunjukkan bahwa kemampuan koneksi matematis pada kedua kelompok yang diberikan perlakuan berbeda memiliki perbedaan yang cukup signifikan. Hasil analisis data baik analisis deskriptif maupun pengujian hipotesis berdasarkan analisis varians (ANAVA) dua jalur menunjukkan bahwa terdapat perbedaan kemampuan koneksi matematis kelompok siswa yang mendapat perlakuan model pembelajaran CTL dengan kelompok siswa yang mendapat perlakuan pembelajaran ekspositori. Berdasarkan data deskriptif diperoleh rata-rata n-gain kemampuan koneksi matematis kelompok siswa yang mendapat model CTL adalah 0,390 sedangkan skor rata-rata n-gain kemampuan koneksi matematis kelompok siswa yang mendapat pembelajaran ekspositori adalah 0,266. Dengan demikian dapat disimpulkan bahwa peningkatan

\footnotetext{
Pengaruh Contextual Teaching and Learning dan Self Regulated Learning terhadap Kemampuan 
kemampuan koneksi matematis antara kelompok siswa yang mendapat perlakuan model CTL lebih tinggi dari pada kelompok siswa yang mendapat perlakuan pembelajaran ekspositori.

Pada kelas eksperimen menggunakan model pembelajaran CTL membuat siswa lebih aktif dalam menyelesaikan soal. Model pembelajaran CTL merupakan suatu strategi pembelajaran yang menekankan kepada proses keterlibatan siswa secara penuh untuk dapat menemukan materi yang dipelajari dan menghubungkannya dalam situasi kehidupan nyata sehingga mendorong siswa untuk dapat menerapkannya dalam kehidupan mereka. Pada model pembelajaran CTL siswa dituntut untuk dapat mengembangkan pemikirannya, menjadikan pengetahuan siswa lebih bermakna karena dengan model pembelajaran CTL siswa bekerja sendiri, menemukan sendiri, dan mengkonstruksi sendiri pengetahuan dan keterampilan barunya.

Sedangkan pada kelas kontrol guru hanya memberikan materi melalui ceramah dan pemberian contoh soal. Semua materi dan contoh permasalahan telah dijelaskan oleh guru, komunikasi hanya cenderung satu arah yaitu dari guru ke siswa, sedangkan siswa kurang diberi kesempatan untuk memecahkan permasalahannya sendiri. Hal ini membuat siswa menjadi tidak memiliki keinginan yang kuat untuk menghubungkan pengetahuan yang telah dimilikinya kedalam pengetahuan baru yang akan didapatkannya. Dengan demikian dapat disimpulkan bahwa model pembelajaran contextual teaching and tearning berpengaruh terhadap kemampuan koneksi matematis siswa.

\section{Terdapat Pengaruh Self-Regulated Learning Terhadap Kemampuan Koneksi Matematis Siswa}

Berdasarkan hasil uji hipotesis ke 2 terlihat nilai signifikansi lebih kecil dari 0,05, hal ini menandakan bahwa terdapat pengaruh yang signifikan antara SRL terhadap kemampuan koneksi matematis siswa. Kemampuan Koneksi matematika merupakan kemampuan individu untuk mengidentifikasi kecukupan data untuk memecahkan

Self-regulated learning adalah suatu upaya siswa aktif untuk mengembangkan pengetahuan yang didapat dengan menggunakan cara-cara yang relevan dan tidak terbatas hanya pada materi pelajaran yang didapat siswa dari lingkungan sekolah. Siswa yang terbiasa aktif dalam belajar akan tumbuh dalam dirinya kemandirian belajar. Dengan demikian terdapat pengaruh antara SRL dengan koneksi matematis siswa.

\section{Terdapat interaksi antara model pembelajaran dan self-regulated learning terhadap peningkatan kemampuan koneksi matematis.}


Hasil pengujian hipotesis yang ketiga menunjukkan bahwa ditemukan adanya pengaruh interaksi antara model pembelajaran dan self-regulated learning terhadap kemampuan koneksi matematis. Berdasarkan gambar 4.1 grafik interaksi model pembelajaran dan SRL terhadap kemampuan koneksi matematis. Pada grafik tersebut menunjukkan bahwa terdapat pengaruh yang signifikan terhadap kemampuan koneksi matematis.

Penerapan model pembelajaran dan sikap masing-masing yang dimiliki siswa SRL tinggi, SRL sedang dan SRL rendah dalam belajar akan mempengaruhi kemampuan koneksi matematis. Sehingga dapat disimpulkan terdapat interaksi antara model pembelajaran dan self-regulated learning terhadap kemampuan koneksi matematis siswa.

\section{Peningkatan kemampuan koneksi matematis siswa SRL Tinggi yang belajar} menggunakan model pembelajaran CTL lebih tinggi dibandingkan dengan siswa SRL Tinggi yang menggunakan model pembelajaran ekspositori

Hasil pengujian hipotesis keempat menunjukkan bahwa kemampuan koneksi matematis pada kelompok siswa SRL tinggi yang mendapat perlakuan model pembelajaran CTL lebih tinggi dari pada yang mendapat pembelajaran ekspositori. Sedangkan kelompok siswa dengan SRL sedang dan SRL rendah yang mendapat perlakuan model pembelajaran CTL tidak telihat perbedaan yang signifikan dibandingkan dengan kelompok SRL sedang dan rendah yang mendapat perlakuan model pembelajaran ekspositori.

Berdasarkan paparan di atas dapat disimpulkan bahwa perbedaan kemampuan koneksi matematis matematika pada siswa dengan SRL tinggi yang diberi perlakuan model pembelajaran CTL lebih tinggi dari pada siswa SRL tinggi yang diberi perlakuan pembelajaran ekspositori.

\section{SIMPULAN DAN SARAN}

\section{Simpulan}

Berdasarkan hasil penelitian dan pembahasan bab IV tersebut diperoleh kesimpulan sebagai berikut.

1. Peningkatan kemampuan koneksi matematis siswa yang mendapat model pembelajaran CTL lebih tinggi dari pada siswa yang mendapat pembelajaran ekspositori. Maka model pembelajaran CTL perlu diterapkan dalam proses pembelajaran.

\footnotetext{
Pengaruh Contextual Teaching and Learning dan Self Regulated Learning terhadap Kemampuan 
2. Terdapat pengaruh yang signifikan antara self-regulated learning dengan koneksi matematis siswa. Hal ini menunjukan bahwa koneksi matematis dapat dipengaruhi oleh SRL.

3. Terdapat interaksi antara metode pembelajaran dan self-regulated learning terhadap kemampuan koneksi matematis. Hal ini menunjukkan bahwa peningkatan kemampuan koneksi matematis siswa secara bersama-sama dipengaruhi oleh model pembelajaran dan self-regulated learning.

4. Peningkatan kemampuan koneksi matematis siswa dengan self-regulated learning tinggi yang diberi perlakuan model pembelajaran CTL lebih tinggi dari pada yang diberi perlakuan pembelajaran ekspositori. Hal ini menunjukan bahwa peningkatan kemampuan koneksi matematis siswa yang diajar dengan model pembelajaran CTL dipengaruhi oleh level SRL yang tinggi.

\section{Saran}

Berdasarkan kesimpulan di atas, penulis mengemukakan beberapa saran sebagai berikut.

1. Bagi guru matematika, pembelajaran dengan model pembelajaran CTL dapat digunakan sebagai model pembelajaran dikelas dalam upaya meningkatkan kemampuan koneksi matematis siswa.

2. Guru dalam menerapkan model pembelajaran CTL harus memperhatikan penyusunan kelompok belajar, sehingga setiap kelompok terdiri dari siswa yang mempunyai selfregulated learning yang heterogen karena sangat mempengaruhi jalannya belajar di kelas.

3. Bagi sekolah diharapkan mampu membuka wawasan bagi guru terhadap inovasi untuk mengembangkan model-model pembelajaran, serta memberi dukungan sepenuhnya pada guru dengan menyediakan berbagai fasilitas yang dibutuhkan untuk proses pembelajaran yang lebih baik.

4. Bagi peneliti hendaknya dapat mengadakan penelitian dengan mengkombinasikan berbagai model pembelajaran lainnya untuk meningkatkan kemampuan koneksi matematis siswa.

\section{DAFTAR PUSTAKA}

Arikunto, Suharsimi. (2006). Prosedur Penelitian. Jakarta: Rineka Cipta

Depdiknas. (2007). Kurikulum Tingkat Satuan Pendidikan. Jakarta: Depdiknas. 
Djamari, S.B. (2002). Rahasia Sukses Belajar. Jakarta: Rineka Cipta

Fasikhah, S. S., dan Siti Fatimah. (2013). Self-Regulated Learning Dalam Meningkatkan Prestasi Akademik Pada Mahasiswa. Jurnal Ilmiah Psikologi Terapan. Ano. Vol. 01: 142-152.

Fitria, D.H. (2009). Pengaruh Kemandirian Belajar Siswa terhadap Prestasi Belajar Matematika di SMP Negeri Depok.

Gordah, E. K. (2009). Meningkatkan Kemampuan Koneksi dan Pemecahan Masalah Matematik melalui Pendekatan Open Ended. Tesis_(tidak diterbitkan). Bandung: UPI

Harahap, H. (2015). Penerapan contextual teaching and learning untuk meningkatkan kemampuan koneksi dan representasi matematika siswa: Jurnal Edu Tech [online] tersedia. $\quad$ https $/ /$ article. Phps $?$ article $=334437 \&$ val $=7834 \&$ title $=$ Penerapan Contextual Teaching And Learning (CTL) Untuk Meningkatkan Kemampuan Koneksi dan Refresentasi Matematika Siswa.Vol 1 (1). [25 November 2017].

Indrawan R. dan Yuniawati, P. (2014). Metodologi Penelitian. Bandung: PT. Refika aditama.

Izzati, N. (2010). Meningkatkan Kemampuan Berpikir Matematis pada Tingkat Koneksi dan Analisis Siswa MTs Negeri Melalui Pembelajaran Kolaboratif MURDER. Tesis. PPs UPI Bandung. Tidak diterbitkan.

Kadir. (2016). Statistika Terapan (2(3)). Jakarta Rajawali Pers.

KusumaW, A., Y. (2013). Penerapan Pembelajaran Reciprocal Teaching untuk Meningkatkan Kemampuan Pemecahan Masalah Matematika Siswa SMP. Skripsi UPI. Bandung: Tidak Diterbitkan

Lestari, K. E dan Ridwan, M. (2015). Penelitian Pendidikan Matematika. Bandung: Refika Aditama.

Lestari, K. E,. dan Yudhanegara, M.R. (2017). Penelitian Pendidikan Matematika. Bandung: Refika Aditama.

Lestari, N. A., dan Widada, W. (2017). Pengaruh Strategi Pembelajaran Self Regulated Learning In Mathematics Berbasis Pemecahan Masalah Terhadap Kemampuan Metakognitif Siswa di SMA Negeri, 2 (2).

Narendrati, N. (2017). Komparasi Pembelajaran Statistika Melalui Pendekatan CTL dan Problem-Posing Ditinjau dari Prestasi Belajar dan Minat Belajar Matematika $A$ Comparison of Statistics Learning Through CTL and Problem-Posing Approach in Terms of Learning Achievement and Intere, 4(1), 67-77.

Pengaruh Contextual Teaching and Learning dan Self Regulated Learning terhadap Kemampuan Koneksi Matematis Anwar, Pujiastuti, Mutaqin 
Nartani, I. (2015). Communication in Mathematics Contextual. International Journal of Innovation and Research in Educational Sciences. Tersedia: http//ijires.org/administrator/components/com_jresearch/files/publications/IJIRES_314 _Final.pdf Volume 2, Issue 4, ISSN (Online): 2349-5219. [20 Agustus 2018] Nasution, S. (2010). Berbagai Pedekatan dalam Proses Belajar Mengajar. Bandung: Bina Aksara.Mahasiswa Calon Guru Matematika. Bandung: Jurusan Pendidikan Matematika FPMIPA UPI.

NCTM. (1989). Curriculum and Evaluation Standards for Cshool Mathematics. Reston, VA: NCTM

NCTM. (2000). Principles and Students for School Mathematics. Reston, VA: NCTM

Nurdiawati. (2015). Peningkatan Kemampuan Penalaran Matematis dan Kemandirian Belajar Siswa Madrasah Tsanawiyah (MTs) melalui Pendekatan Contextual (CTL) tersedia:. http//jurnal.unsyiah.ac.id/DM/article/view/2815/2688. Jurnal Didaktik Matematika.Vol.2, No. 2, [24 September 2018. (online).

Permana,Y dan Sumarmo, U. (2007). Mengembangkan Kemampuan Penalaran dan Koneksi Matematik Siswa SMA Melalui Pembelajaran Berbasis Masalah. Kumpulan Jurnal UPI. Vol.1 No.2 Juli 2007. (online).: [22 Agustus 2018]

Ramdani, Y. (2011). Pembelajaran Untuk Meningkatkan Kemampuan Berfikir Tingkat Tinggi Melalui Pendekatan Contextual Learning and Teaching: Jurnal Didaktik Matematika [online] Vol 2 (1). [02 September 2018]

Ratnaningsih C. (2012). Model grup Investigasi (GI) untuk meningkatkan kemampuan Koneksi matematis dan kemamdirian belajar siswa SMP.Tesis Pascasarjana UNPAS: Tidak diterbitkan

Riduwan. (2010). Metode dan teknik Menyusun Tesis.Bandung: Alfabeta Riyanto, Yatim. (2010). Metodologi Penelitian Pendidikan. Surabaya: SIC

Rohendi, D. dan Dulpaja, J. (2013). "Problem Solving in School Mathematics Based on Heuristic Strategies", Journal of Education and Practice, Vol.4, No.4, ISSN 22221735 (Paper) ISSN 2222-288X (Online). [01 September 2018]

Ruseffendi, E. T. (2005). Dasar-Dasar Penelitian Pendidikan dan Bidang Non Eksakta Lainnya. Bandung: Tarsito.

Ruseffendi, E.T. (2006). Pengantar kepada Membantu Guru Mengembangkan Kompetensinya Dalam Pengajaran Matematika untuk Meningkatkan CBSA. Bandung: Tarsito 
Ruspiani. (2000). Kemampuan Siswa dalam Melakukan Koneksi Matematika.Tesis Pasca Sarjana Universitas Pendidikan Indonesia, tidak diterbitkan, Bandung PPs UPI.

Sanjaya W. (2003). Strategi Pembelajaran Berorientasi Standar Proses Pendidikan. Bandung. Somakim. (2010). Penigkatan Kemampuan Berpikir Kritis dan Self-efficacy Matematika Siswa Sekolah Menengah Pertama dengan Penggunaan Pendekatan Matematika Realistik. Disertasi SPs UPI. Bandung: Tidak Diterbitkan.

Sudjana. (2005). Metode Statistika. Bandung: Tarsito

Sugityono. (2013). Berfikir dan Disposisi Matematik serta Pembelajarannya. UPI : Bandung. Sugiyono. (2010). Metode Penelitian Pendidikan Pendekatan Kuantitatif, Kualitatif dan R dan D. Bandung: Alfabeta.

Sugiyono. (2012). Statistika untuk Penelitian. Bandung: ALFABETA

Suherman, E. (2003). Evaluasi pembelajaran Matematika. Bandung: JICA

Sumarmo, U. (2004). Kemandirian Belajar : Apa, Mengapa dan Bagaimana dikembangkan Pada peserta didik. Makalah diajukan Pada Seminar pendidikan matematika jurusan matematika FPMIPA.Universitas Negeri Yogyakarta, tgl 08 Juli 2004.Tidak diterbitkan Sumarmo, U. (2010). Pengembangan Berfikir Matematika Tingkat Tinggi Siswa SLTP dan SMU serta Mahasiswa Strata Satu (S1) Melalui Berbagai Pendekatan Pembelajaran. Laporan Penelitian Lemlit UPI.

Trisnawati, T. (2015). Penggunaan Model Pembelajaran Matematika Knisley (Mpmk) Untuk Meningkatkan Kemampuan Koneksi Matematis Dan Self Confidence Siswa Mts. Tesis Unpas Bandung: Tidak diterbitkan.

Uyanto, S.S. (2006). Pedoman Analisis Data dengan SPSS. Yogyakarta: Graha Ilmu.

Wardatul. S. F. (2015). Kemampuan Koneksi Matematis ditinjau dari Lokus Kendali Dalam Soal Persamaan Garis Lurus di SMP. Kumpulan Jurnal Untan. Vol, 1-10, 2015. (online) [25 September 2018]

Zimmerman, B.J dan Schunk, D. H. (1989) (Eds). self regulated Learning and Academis achievment: Theory, Research, and Practice. New York: Springer-Verlag. 